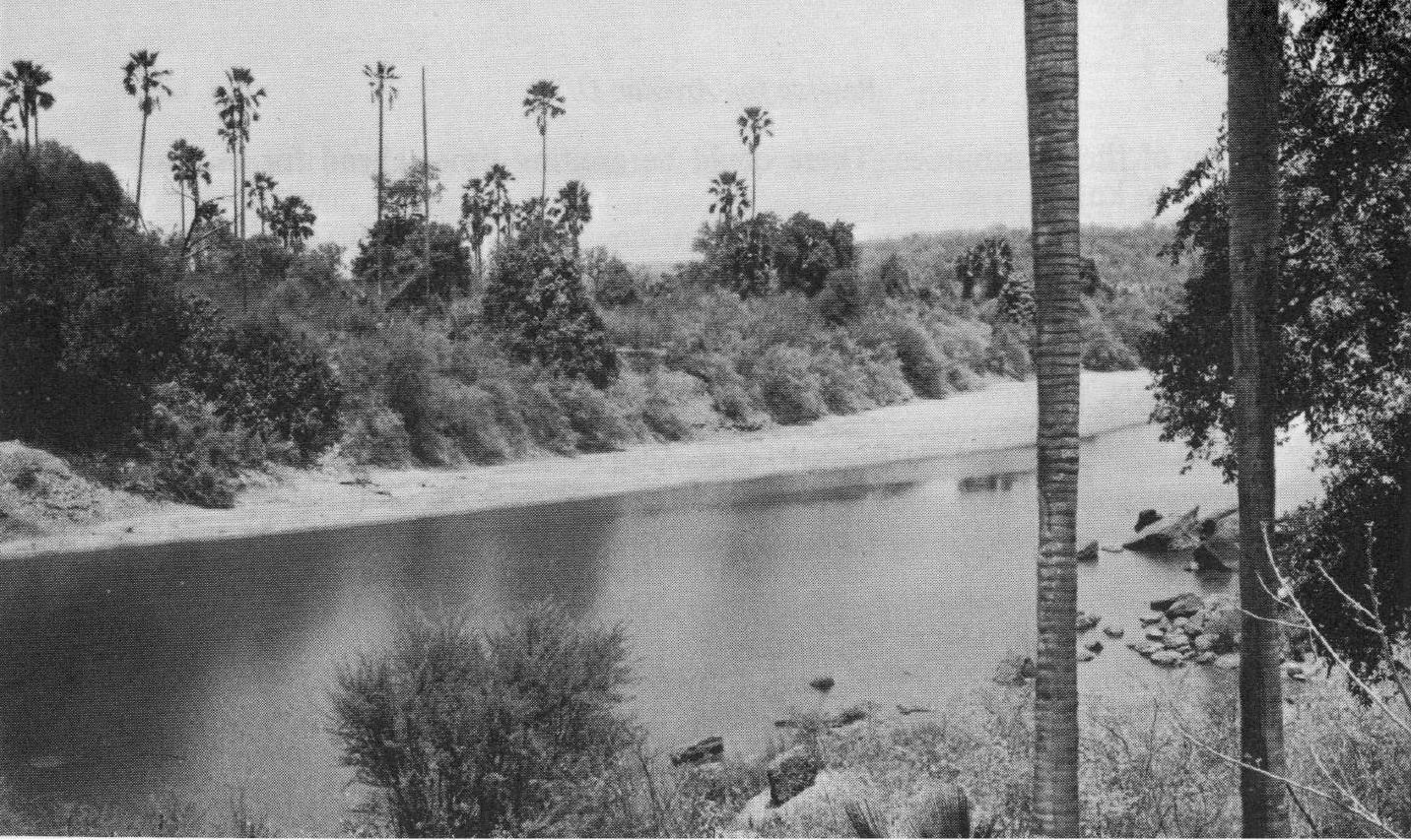

\title{
Wildlife and Parks in Senegal
}

\section{A. R. Dupuy and J. Verschuren}

The Director of National Parks in Senegal and a well-known European conservationist survey the wildlife, especially mammals, of this conservationconscious West African country, where three new national parks have been declared in the last eighteen months. One of the highlights of the enormous Niokolo-Koba park is the giant Lord Derby's eland Taurotragus derbianus of which there are now over 400 .

The fauna of West Africa has received far less attention than that of Central or East Africa. Few people, even zoologists, if asked 'Where are the nearest elephants and hippos to western Europe?' would immediately reply 'Senegal'. Obviously the West African savannas have never harboured ungulates in numbers comparable with those of East Africa - for reasons which are not very clear, but possibly edaphic. Nevertheless, wildlife is still abundant in some areas, and Senegal is a typical example. For some years wildlife conservation there has been notably effective, and the results set an example for many other countries, not only in Africa.

Senegal covers $196,000 \mathrm{sq} \mathrm{km}$ in the extreme west of Africa, approximately between latitudes $12^{\circ}$ and $17^{\circ} \mathrm{N}$. The country is generally flat, apart from the volcanic peaks of Cape Verde and the last buttresses of the Fouta Djalon, where there are spectacular deep valleys. Rainfall decreases from the south towards the north, varying from $1500-1600 \mathrm{~mm}$ at Ziguinchor to $400-450 \mathrm{~mm}$ at St Louis, with less than $200 \mathrm{~mm}$ in the Bakel region. If a large part of the country is in a sudanese zone, the north is plainly sahelian and the south clearly pre-guinean. Vast wooded savannas of various types cover the country,

Borassus palms by the river Gambia which drains the greater part of Niokola-Koba park 
NATIONAL PARKS

A. Niokolo-Koba

B. Djoujd

C. Lower Casamance

D. Saloum Delta

E. Langue de Barbarie

F. Iles de la Madeleine Not to scale, except for Niokola-Koba

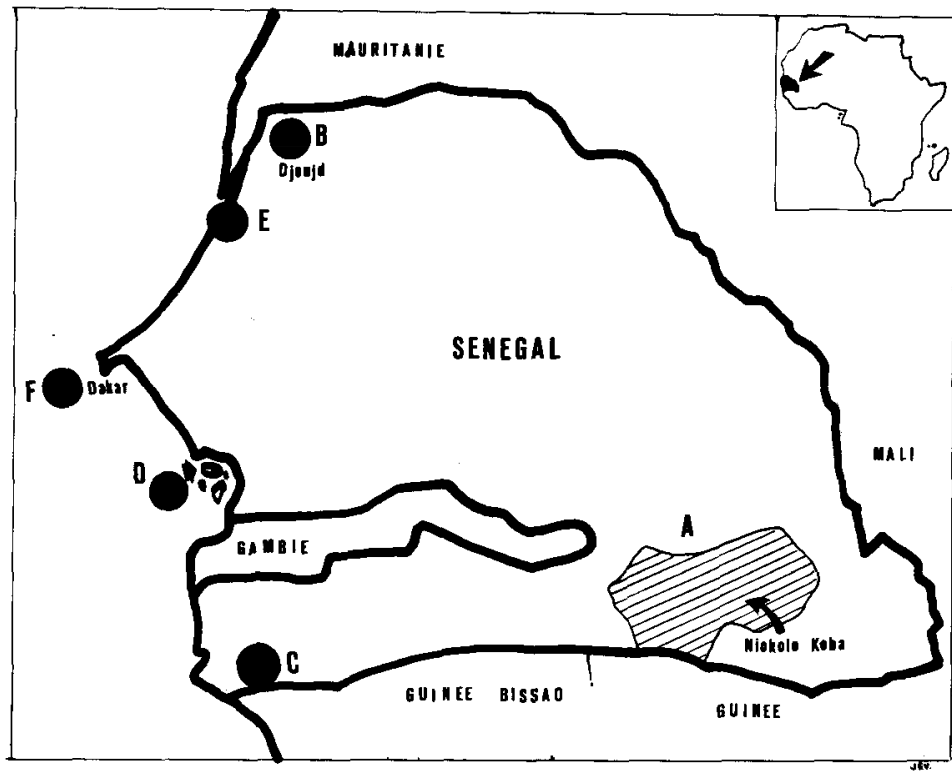

while the important galleries are along the banks of the rivers in the south. The main rivers are the Senegal, Gambia and Casamance and their tributaries, whose levels vary enormously through the year. The human population - over four million in 1976 - is 85 per cent Muslim and thins out progressively towards the east of the country, ranging from over 400 to the square kilometre in the Cape Verde to about 5, with vast zones in the east almost empty. Peanuts are still the basic crop and main export, but livestock is also plentiful.

Senegal was one of the first African countries to be colonised by Europeans, and for many years the wildlife was massacred. But in 1925 a large park, the Niokolo-Koba, was created 'in extremis', and although protection was not really effective until after 1960 , the area was gradually doubled. Since then another five parks have been established. Wildlife is largely confined to these national parks, although a viable fauna survives in the hunting reserves and even in some open zones.

Today the Senegal Government gives nature conservation a real priority, and a significant budget. Personnel includes about 450 guards, mostly trained soldiers, armed with rifles, plus about 200 temporary workers. The National Parks Service, within Dakar, comes under the direct responsibility of the Prime Minister through the Délégation Générale du Tourisme - undoubtedly the best arrangement. The national parks, which are effective units and not just paper concepts, cover almost 4 per cent of the country, comparing favourably with Zaïre's 2.7 per cent (10-15 per cent forecast), Kenya's 4 per cent, Zambia's 8 per cent and Rwanda's 10 per cent.

The aim in Senegal is to protect as many ecosystems as possible, constituting complete ecological units so that the entire conspectus of large ungulates and carnivores can survive intact. Because of the country's geographical situation, particular emphasis has been placed on protecting areas used by migrating birds. The national parks' three basic missions are conservation, scientific research and the promotion of controlled tourism. Samples of almost all the types of natural environment are being preserved, either in considerable areas, e.g. c. 900,000 ha of sudanese habitat, or in smaller but still viable areas, e.g. 5000 ha of pre-guinean habitat. 
ratio, and sightings, though not frequent, are not exceptional. Other herds are known to exist far from the park limits on the Falémé, near the Mali border and also near Kolda between Casamance and the Gambia, but although protected, their future is plainly more problematical. Niokolokoba also has herds of the large bubal hartebeest Alcelaphus buselaphus major, of which an extinct race survived in Morocco as recently as 1925; there is a Senegalese-Moroccan project to reintroduce it in eastern Morocco.

The major predators, lion and leopard, are not very numerous. Hyenas and wild dogs Lycaon pictus are common, and warthogs, which are not hunted by the local people, who are mostly Muslim, have increased greatly; they are abundant throughout the country, even near cultivated areas, and above all in the Senegal delta, where expanding rice cultivation encourages them. Bush-pig Potamochoerus porcus porcus are also numerous in all the forest galleries of eastern Senegal and Casamance.

Baboons are ubiquitous. Numbers have increased considerably with the reduction of their predators, and it is not unusual to see troops of more than 500. The total population - at least 100,000 - is high, but spread over more than $8000 \mathrm{sq} \mathrm{km}$, means no more than 12-15 per sq $\mathrm{km}$. This is not excessive compared with the human populations of Europe or SE Asia, where Homo sapiens proliferans pollutans exceeds 400 per sq $\mathrm{km}$ and is similarly omnivorous. Only after thorough scientific research, if then, should numbers be reduced. Moreover, local overpopulation provides interesting opportunities for the study of aggression in a highly gregarious primate undergoing a demographic explosion in a limited territory. We have to be cautious before culling 'overpopulous' animals in a nature reserve, and one of the major reasons is psychological. How do you explain to the indigenous people near the park, who are often short of protein but may be gaoled for occasionally taking a guineafowl or small antelope, why the authorities are killing hundreds of animals and being paid for it? Whatever the ecological reasons, the men of the bush are bound to feel victimised and that dual standards are operating. Neither do tourists expect to hear shots in a national park or see lorry-loads of 'legally' killed animals. Of course this does not mean that there should be no management but the rare cases in which killings are justified must be fully considered and carried out with maximum discretion.

The discovery of chimps in Niokolo-koba came as a complete surprise, for they inhabit biotopes very different from those of the equatorial forest, and sometimes one can almost talk of 'savanna chimpanzees'. Interesting conclusions on this subject may be drawn from Kortlandt's studies. Near Mont Assirik a team led by Miss Stella Brewer is attempting the re-introduction of orphan chimpanzees (some taken from poachers' camps, some bred in European zoos) with all necessary caution with regard to the possibility of genetic interference. This project can be compared with Joy Adamson's work with the lions of East Africa. It is interesting that, like the elephants, hippos, buffaloes and several other species in Niokolo-koba, the chimpanzees are here found at the absolute limit of their known geographical range both north and west.

Niokolo-koba is patrolled daily by 200 guards who live with their families in isolated posts, some 'at the back of beyond'; many camps have to be evacuated at the height of the rainy season because of floods. The radio network is one of the best in any African reserve, giving daily contact with the 
African manatees Trichecus senegalensis were trapped in the Taouey channel as a result of some construction work. They were successfully immobilised and captured; three released in the Djoudj park and four in Lake Guiers. As with Niokolo-koba, damming projects could have serious effects on this reserve, threatening to break the delicate natural equilibrium of the water. Intensive upstream cultivation using sophisticated techniques would raise the level of herbicide and pesticide residues in the main river, the first victims of which would be the region's fishermen, possibly followed by the inhabitants of Saint Louis.

\section{Lower Casamance}

The Lower Casamance National Park is in the extreme south which has nothing in common with northern Senegal. The first impression is more Zaïrois than Senegalese, with leaden skies and dark forests, and a dense human population on the rich, well-watered soils. A thousand difficulties had to be overcome to preserve intact this small 'island' of nature representing the various local biotopes, including mangroves and rain forest. The fauna is already very southern, for one is almost certain to see mona monkey Mona campbelli, which is exclusive to the area, and sitatunga Tragelaphus spekei is also found, as is the yellow-backed duiker Cephalophus sylvicultor, which emphasises the type of forest and, above all, the relict nature of the animal population. The typically forest birds, such as the yellow-casqued hornbill Ceratogyma elata and the crowned eagle Stephanoëtus coronatus, provide additional evidence. Otters Aonyx capensis can be seen under exceptional conditions.

\section{New Reserves}

Since January 1976 three new reserves have been created. The Madeleine Islands National Park, opposite Dakar, is a very beautiful marine park, one of the few rocky habitats of continental west Africa, and the nesting place of some 30 pairs of red-billed tropic birds Phaethon aethereus mesonanta. The Langue de Barbarie National Park to the north, opposite the country's second largest town, St Louis de Sénégal, has nesting colonies of slenderbilled gulls Larus genei, Caspian terns Hydroprogne tschegrava and grayheaded gulls $L$. cirrocephalus. This park represents the southern breeding limit of a certain number of palearctic birds such as gull-billed tern Gelochelidon nilotica and little tern Sterna albifrons, and the northern nesting limit of southern species such as royal tern Sterna maxima albidorsalis. The nests in the colonies total several thousand. The most recent creation, the Saloum Delta National Park, $200 \mathrm{~km}$ south of Dakar, was fraught with difficulties. The park consists of a mosaic of sandy islands and lagoons, with a wide variety of mangrove swamps - the most northerly in Africa - in the delta of the seasonal Sine and Saloum rivers, and also part of the dry forest of Fathala that shelters more than 600 western red colobus, almost the most northerly of the continent. Its present area, about 60,000 ha, including the coastal waters, constitutes a compromise: the inner islands are too few in number and, most serious, the flats, those extraordinary salty expanses, burned by the sun, are excluded. However, even within its ecologically unsatisfactory limits, the park's creation is a real success. In the long term the fishermen, who are not prohibited in the reserve, will come to realise that they 


\section{Conservation Policy}

Senegal's national parks are not actually strict nature reserves, i.e. reserves that are integrally protected. Vast areas, especially in the Niokolo-koba, constitute fully protected environments, where interventions by man are limited and varied, facilities are provided for tourists (viewpoints, tracks, lodges etc.) and strictly controlled bush fires are carefully planned and constantly monitored. A large part of eastern Senegal is covered by savanna which is a veritable 'fire-climax', and moreover natural fires there are not unusual - from storms, 'natural magnifying glasses', or sparks from animals' hooves. Radical suppression of the fires would modify the diversity of plant species and totally change the numbers of large ungulates.

In the Djoudj National Park management of the water supply has proved extremely effective; in other reserves there is little need to create watering points. Artificial dams have upset too many reserves elsewhere, causing overpopulation and degradation of the soils and the grazing.

Scientific research is a major preoccupation of the Senegal national parks. Numerous experts - University of Dakar, IFAN*, CNRS, ORSTOM, CRMMO, Muséum National de Paris, etc - have studied various problems, and FAO, UNESCO, IUCN, UNEP, WWF and various foreign foundations, including the Frankfurt Zoological Society, take a close interest. In particular it is hoped to create a large international bird-ringing centre in the Djoudj National Park through which large numbers of European migrants pass. Senegal is also a source of major interest because it lies at the present northern range limits of several large ungulates and other mammals. From the north to the south the isohyets (joining places with the same rainfall) are very close together; palaearctic and Ethiopian fauna meet in the north of the country, along the Atlantic coast. Moreover, Senegal was one of the first countries south of the Sahara to be explored by zoologists and botanists, innumerable zoological and botanical types originated in this country, and many animals and plants bear the specific name senegalensis - hence the interest in protecting what remains.

The national parks play an essential role in the development of tourism, for which Senegal is a veritable spearhead in French-speaking Africa, being the nearest African country to western Europe that offers winter sunshine and warmth, with Dakar only three hours away (by Concorde) and all the reserves easily accessible on arrival. Tourism is on the increase, and fortunately the protected areas are large enough to cope, with well organised circuits, plenty of lodges, and several airfields - and tourists do not yet outnumber the animals. (In one East African park recently a female black rhinoceros and her baby were encircled by 21 minibuses.) Outside the reserves there is wildlife in the hunting areas managed by the Department of Water, Forests and Hunting, and in the open hunting areas. Elephants are only to be found in Niokolo-koba, except in the rainy season when some invariably leave the park; occasionally they are reported in the Matam area (River Senegal) and on the Guinea-Bissau border in the region of the Kayanga river and W. Koulounton. Hippos are still found in small numbers, both in the upper

* IFAN: Fundamental Institute of Black Africa; CNRS: National Centre for Scientific Research; ORSTOM: Overseas Office of Scientific and Technical Research; CRMMO: Center for Research on Mammalian and Avian Migration. 


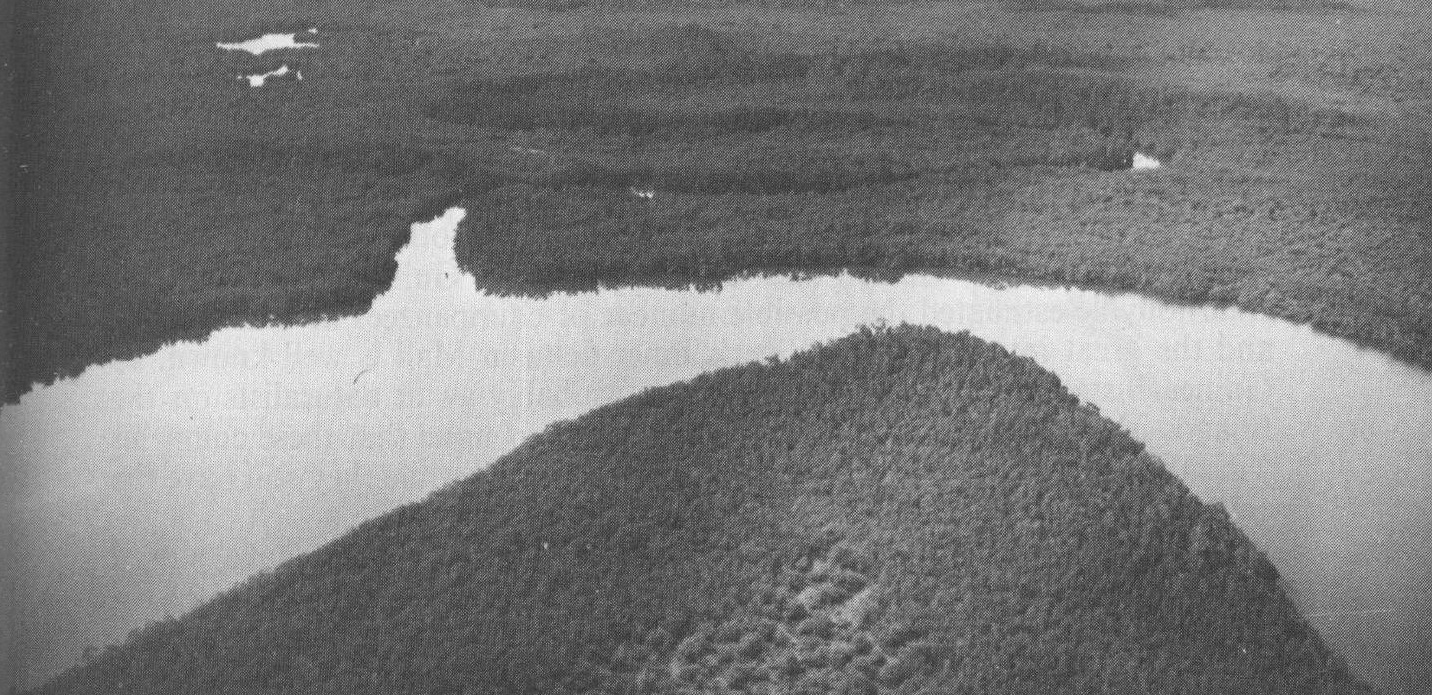

MANGROVES and RAIN FOREST in the Lower Casamance National Park J.Verschuren

reaches of the $\mathrm{R}$. Falémé and lower Casamance, and a few along the Gambia river, both in Senegal and The Gambia. Buffaloes are found in satisfactory numbers in all the eastern part of East Senegal south of the metalled road, and the nanus form survives in lower Casamance, near the park and on the GuineaBissau border. Eland survive in a few places outside the Niokolo-koba park, and roan and hartebeest Alcelaphus busephalus still frequent the plateaus of the south-east, especially the region between Mali, Tambacounda and Kédougou. The small species of habitually sedentary ungulates such as oribi and bush duiker Sylvicapra grimmia are persecuted by hunters and are disappearing everywhere outside reserves. The status of predators outside the protected zones, especially lions, is very precarious, for the lack of wild prey forces them to kill cattle; in another ten years they will probably have been exterminated wherever man is present with his herds.

In hunting areas and forests classed as of hunting interest, both managed by the Service des Eaux et Forêts, the small fauna survives but is exploited through controlled hunting (on licences or safaris). The dominant species remains the warthog thanks to a largely Muslim population which does not eat pork, but even it is under threat from the extension of cultivated areas, for warthogs do much damage in the rice-fields and massive slaughterings are organised to destroy them. These reasons, coupled with the likely destruction of its environment by the Senegal valley being cultivated after irrigation, make its future insecure and it will probably become rare in the north except inside the Djoudj park.

The conservation situation in neighbouring countries is of some importance to Senegal. The Gambia has a small nature reserve - the Abuko Park - (see Oryx 1973, 10,5) and plans the creation of four national parks one of which will be a southerly continuation of Senegal's new Saloum Delta park, and give West Africa its first international park. Undoubtedly Mauritania, where considerable efforts have been made in recent years, is an important neighbour. The Banc d'Arguin, southwest of Nouadhibou, an ornithological site of world interest, has just been declared a reserve and implementation is awaited. One of the last colonies of the severely threatened monk seal Monachus monachus is in the cliffs near Nouhadibou; can it be saved? Nothing is known of the hypothetical relict elephant of Mauritanian Adrar, which 
would be the most northerly of all. In the Mauritanian part of the Senegal delta, there are areas of free water which would complete the Djoudj national park in Senegal and should have protection. Three other countries march with Senegal: Mali, Guinea and Guinea-Bissau. In Guinea, ten years ago, Bournonville estimated the possible number of chimpanzees at over 12,500 , and the great interest of the Niger's inner delta in Mali is well known. In Guinea-Bissau, moreover, some surprises probably await naturalists on the Bijagos islands which are difficult to reach. Let us hope that these countries will take measures to preserve their wildlife potential while they still have the chance.

In Senegal, where most of the staff directing the reserves have passed through the Garoua Institute, the outlook for the future is encouraging. One priority is to make people aware of the problems of nature conservation, and a parks team equipped with an all-terrain vehicle fitted with audio-visual equipment, a gift from WWF, has been formed for this purpose, and will carry its message into villages in the deepest bush as well as to the urban crowds of Dakar and other big towns who have never seen a wild animal.

In the immediate future the three most severely poached animals must be saved: elephant, leopard and crocodile; the pillage of nesting colonies of aquatic birds and sea turtles must be stopped. Senegal hopes for increased co-operation with international organisations, and has made a considerable contribution for nature protection from its own national budget, one of the highest on the African continent. In protecting its own fauna and migrants Senegal is making a real gift to the population of the industrialised countries. Many African heads of state have also shown their desire to protect their natural heritage. Can one assert that the same is true of the so-called industrialised countries? Africa even more than the other continents is aware of this primordial problem of conservation.

Recently the President and Prime Minister of the Republic of Senegal declared:

'Above all we wish to preserve a vast area, some 800,000 ha of the SudanoSahelian zone against the destructive fury of hunters. And behold the park has become a paradise for the hunters of pictures and a compulsory stopping place for the tourists who visit Senegal. I hope they will rediscover there something of the joys of earthly paradise'.

Léopold Sedar Senghor, President

'The protection of the environment is not merely a fashionable theme: in a world where the pollution of the towns, air and water are in some places becoming insupportable, it has become one of the major exigencies of our time. Our environmental policy based on the protection of the national parks, their fauna and flora, forms part of an ethic destined to place development at the service of man, and to reconcile it with the need to preserve the natural environment'.

Abdou Diouf, Prime Minister

A. R. Dupuy, Directeur des Parcs Nationaux du Sénégal, BP 5135, DAKAR, Senegal.

J. Verschuren, Institut Royal des Sciences Naturelles de Belgique, 31 Rue Vautier, BRUXELLES 1040, Belgium. 